\title{
Heavy Metals: The Notorious Daredevils of Daily Personal Care Products- Mini Review
} \author{
Bangladesh

\section{*Corresponding Author} \\ Abdul Kader Mohiuddin \\ Article History \\ Received: 03.08.2019 \\ Accepted: 27.08 .2019 \\ Published: 30.09 .2019
}

Abdul Kader Mohiuddin*

Assistant Professor, Department of Pharmacy, World University of Bangladesh 151/8, Green Road, Dhanmondi, Dhaka - 1205,

\begin{abstract}
Personal care products and facial cosmetics are commonly used by millions of consumers on a daily basis. Direct application of cosmetics on human skin makes it vulnerable to a wide variety of ingredients. Despite the protecting role of skin against exogenous contaminants, some of the ingredients in cosmetic products are able to penetrate the skin and to produce systemic exposure. Consumers' knowledge of the potential risks of the frequent application of cosmetic products should be improved. While regulations exist in most of the high-income countries, in low income countries there is a lack of similar standards. In most countries for which these legal regulations have been identified, restrictions on the permissible level of heavy metals are strict. There is a need for enforcement of existing rules, and rigorous assessment of the effectiveness of these regulations. The occurrence of metals in cosmetic products is of concern for three principal reasons: (i) the use of cosmetic products could represent a possible source of population-wide exposure daily, and often long-term exposure to metals in cosmetic products (ii) metals can accumulate in the body over time, and (iii) a number of them are known to exhibit different chronic health effects, such as cancer, contact dermatitis, developmental, neurological and reproductive disorders, brittle hair and hair loss. Some metals are potent endocrine disruptors and respiratory toxins. Moreover, some metals, such as $\mathrm{Cd}, \mathrm{As}, \mathrm{Pb}, \mathrm{Hg}$ and $\mathrm{Sb}$, are exceptionally toxic with a wide variety of chronic health effects, whereas $\mathrm{Cr}$, Ni and $\mathrm{Co}$ are well known skin sensitizers. Since the issue of heavy metals as deliberate cosmetic ingredients has been addressed, attention is turned to the presence of these substances as impurities.
\end{abstract}

Keywords: Heavy Metal Toxicity; Personal care products; endocrine disruptors; Cosmetics Safety; Heavy Metal Contamination; Kohl; Cosmetic Regulation; Cosmetic Impurities.

\section{INTRODUCTION}

Cosmetics and personal care products are ubiquitous. The US researchers identified some 12500 industrial chemicals used as cosmetic ingredients, includes carcinogens, pesticides, reproductive toxics, endocrine disruptors, plasticizers, degreasers, and surfactants [4-6]. The US FDA estimated 12,500 chemicals used in cosmetics, $20 \%$ of them are safe according to CIR review, only 11 of them are banned in US but more than 1300 are banned or restricted in the EU [7-9]. Heavy metals such as lead, mercury, cadmium, arsenic and nickel, as well as aluminum, classified as a light metal, are detected in various types of cosmetics (color cosmetics, face and body care products, hair cosmetics, herbal cosmetics, etc.) [10]. The metals are from the contamination of raw materials and use of sub-standard raw materials, lack of compliance by small scale manufacturers, and lack of strict regulations [11]. Also, Alam et al., 2019 says many cosmetic products contain heavy metals as ingredients or impurities [12]. Vella et al., 2019 reported presence of lead in toothpastes were beyond limit of US and EU standards [13]. According to Panico et al., 2019 PEGs (favorably used as penetration enhancers) may contain residual impurities like lead, iron, cobalt, nickel, cadmium, arsenic [14]. ŁodygaChruścińska et al., 2018 detailed nearness of lead and nickel in lipsticks and powders at level restricted by European guideline in Polish market [15]. Applying kajal (otherwise called Kohl or Surma) to infants' eyes is an old custom in numerous societies of the world including Asia, Middle East, European countries, North America and Africa. Kajal or Surma has been reported to contain lead and to be a potential source of lead toxicity in children, which can lead to permanent damage to multiple organ systems [16-18]. A similar Nigerian cosmetic called 'Tiro" applied to the infant's eyelids contained $82.6 \%$ lead which was as high as 70\% in Kajal or Surma [19, 20]. Use of eye cosmetics imported from Pakistan was found to be strongly correlated with elevated blood lead levels [21]. Kohl, a

Copyright @ 2019: This is an open-access article distributed under the terms of the Creative Commons Attribution license which permits unrestricted use, distribution, and reproduction in any medium for non commercial use (NonCommercial, or CC-BY-NC) provided the original author and source are credited. 
type of customary cosmetic product used for eyeliner in the Middle East, contains more than $50 \%$ of lead [22]. A similar study with Malaysian eyeshadows shows the same, lead content exceeding limit of international standard [23]. It has been observed that the blood lead level of eye cosmetics consumers in Pakistan, India, and Saudi Arabia in comparison with non-consumers was threefold. $\mathrm{Cd}$ and $\mathrm{Pb}$ was profound among lipstick samples of Iran and were the most predominant in most Indian cosmetics, along with As [2426]. Lip cosmetics to the digestive tract damages various vital organs once reaching into systemic circulation [1]. A similar study shows predominance of $\mathrm{Hg}$ and $\mathrm{Pb}$ among Indian herbal cosmetics exceeding WHO permissible limit. Very high level of trace metals was reported in locally produced facial makeup in Nigeria [27]. Cobalt is a skin allergen responsible for allergic contact dermatitis (ACD), found higher concentration in shampoo than relaxers and conditioners [28]. In individuals with tattoos containing red pigment of the starting point of mercuric sulfur (cinnabar-vermilion, Chinese red), they may encounter irritation that is restricted to this region inside a half year of tattooing [29]. Sindoor, a corrective powder utilized in Hindu religious and cultural ceremonies has hazardous degrees of lead [30]. The highest concentration of $\mathrm{Pb}$ was found in nettle, $\mathrm{Cd}$ in yarrow, and $\mathrm{Hg}$ in horsetail, plants most commonly used in herbal cosmetics of Poland [31]. Henna, a traditional plant product applied as temporary paint-on tattoos and hair dying, is reported to be very rich in heavy metals such as mercury and lead [32]. Saadatzadeh et al., 2019 reported that arsenic contents of lipsticks, eye shadows, and eyebrow pencils was significantly higher than the BVL (Federal Office of Consumer Protection and Food Safety of Germany) standard [33]. Among the heavy metal impurities, mercury, arsenic, lead, cobalt, antimony, cadmium, nickel and chromium are exceptionally toxic and are prohibited in cosmetics to be included deliberately as ingredients in EU and US [34]. Pb were $\mathrm{Cr}$ are the most profound metals in talcum powder samples [35]. According to Health Canada, 100\% of all cosmetics product tested positive for nickel and over $90 \%$ tested positive for both lead and beryllium and on the average contained at least 4 of the 8 metals of concern (arsenic, cadmium, lead, mercury, beryllium, nickel, selenium, and thallium) [36]. Although titanium's use in sunscreens is regulated, some formulations also include other heavy metals, which are not regulated [37, 38]. Cosmetics use in pregnancy is not uncommon. Schwalfenberg et al., 2018 reported that prenatal lead exposure is associated with a greater risk of premature delivery, reduced postnatal growth, lower mental growth in childhood, schizophrenia and dementia in adulthood [39]. Even low level of $\mathrm{Cd}$ exposure may avert neurodevelopment [40]. Prenatal As exposure has been associated with low growth in utero, low birth weight, head and chest circumference in infants, inflammation and atherosclerotic disease in adults [41]. Also, Li et.al, 2019 reported that heavy metal exposure during fetal period of pregnancy may lead to intrauterine growth retardation [42]. Iron oxides are common colorants in eye shadows, blushes and concealers [43]. Some aluminum compounds are colorants in lip glosses, lipsticks and nail polishes [44]. Aluminum is also used in antiperspirants, sun creams and toothpaste. Chronic disorders currently discussed in connection with aluminum exposure: Alzheimer's disease and breast cancer [45]. The safety assessment by Cosmetic Ingredient Review (CIR) does not include metallic or elemental aluminum as a cosmetic ingredient [46]. Arsenic was known to be poisonous during the Victorian era, but perhaps some women thought that a little bit wouldn't hurt [47]. In addition, some color additives may be contaminated by heavy metals like arsenic, lead and mercury [48]. Heavy metals may be intentionally added to detergents as preservatives, pigments $(\mathrm{Pb})$, skin lightening, as well as antimicrobial agents $(\mathrm{Hg})$ [49]. Significant level of As and $\mathrm{Hg}$ was reported with Mohammad et al., 2017 in skin bleaching agents of Caribbean region [50] As used in skin cream and make-up powder causes skin problems, lung cancer, circulatory and peripheral neuropathy, and increased risk of gastrointestinal and urinary tract malignancies $[51,52]$. Several recent and older studies reported nephrotic syndrome from repeated exposure of mercury and other heavy metals from skin lightening agent [53-58]. Dental amalgam has been used as a restorative treatment in dentistry for well over 170 years. Even after the last mercury dental amalgam is placed, its toxic legacy will continue for decades, because of its pervasive bioaccumulation in the environment, as reported by Tibau et al., 2019 [59]. However, mercury is usually added to skin-lightening products due to its whitening effect. Mercury ions replace tyrosinase enzyme anions, which inhibit the formation of melanin and produce the whitening and anti-freckle effects [60]. Sun et al., 2017 reported that chronic mercury poisoning is associated with irritability, tremor, gingivitis, memory loss, dizziness, insomnia, edema, proteinuria, abdominal pain, nausea, hyperthyroidism, and abortion [61]. Wang et al., 2018 suggested that cumulative exposure to heavy metals as mixtures is associated with obesity and its related chronic conditions such as hypertension and T2DM [62]. Lead poisoning leads to anemia due to jeopardized heme synthesis and acts as a potent reversible and selective blocker of voltage-dependent calcium channels at low concentrations $[63,64]$. Severe damage to the brain and kidneys, both in adults and children, were found to be linked to exposure to heavy lead levels resulting in death [65-75]. In pregnant women, high exposure to lead may cause miscarriage [76-81]. Men exposed to lead mainly from hair colorants [82-85]. Chronic lead exposure was found to reduce fertility in males [86-89]. The 2017 US FDA safety recall to discontinue using Magellan Diagnostics' Lead-Care Testing Systems for analyzing venous blood samples also highlighted the need for improved blood lead testing and surveillance [90]. Ettinger et.al, 2019 reported that economic benefit of lowering lead levels among children by preventing lead exposure has been estimated at $\$ 213$ billion per year [91]. Childhood lead poisoning prevention programs can effectively utilize Medicaid data to increase testing and improve blood lead surveillance [92]. Various sources of acquaintance to chromium exist; including lipstick, eye pencil, eyeliner, eyeshadow, and makeup powder [93, 94]. Cr exists in two valence states, and both oxidation states, i.e. $\mathrm{Cr} 3+$ and $\mathrm{Cr} 6+$ can act as potential haptens causing ACD and skin ulcers [95-99]. Chromium ACD can be a chronic debilitating disease, perhaps because chromium is difficult to avoid. Toxic metals (cadmium, cobalt, copper, nickel and. lead) from body cream basically moisturizers and skin-lightening (toning/bleaching) creams [100]. An increase in level of cadmium has been reported to inhibit DNA repair including mismatch, base excision, and nucleotide excision [101]. Zinc has been reported to cause the same signs of illness as does lead, and can easily be mistakenly diagnosed as lead poisoning [102]. Excess zinc exposure may induce toxic effects on the hematopoietic system, biochemistry and endocrine system function [103]. Skin care experts in the US reckon copper will be this decade's most prominent anti-aging ingredient [104]. Copper delivery through skin can provide beneficial effects but its potential to induce skin irritation reactions is often overlooked [105]. Cobalt and nickel metals commonly found in lipstick, eyeshadow, face paint and hair 
cream associated with contact dermatitis. Cobalt and its salts are widely used as coloring agents in makeup and light-brown hair dyes [31]. Nickel compound exposure can lead to nephrotoxicity, skin irritation and hypersensitivity [106]. Cobalt chloride has a hazard rank of 9 in the Environmental Working Group (EWG) Skin Deep Database and is banned for use in cosmetics by the EU. Since cobalt and nickel are almost always found together, it is wise to avoid both metals [107]. Literature data show that in commercially available cosmetics have potentially toxic metals that may cause danger to human health. This is coupled with prolonged duration of contact, which may occur due to repeated use of the products. There's an old saying that "A thing of beauty is joy forever". But it should be imparted through avoiding beasts inside the beautification.

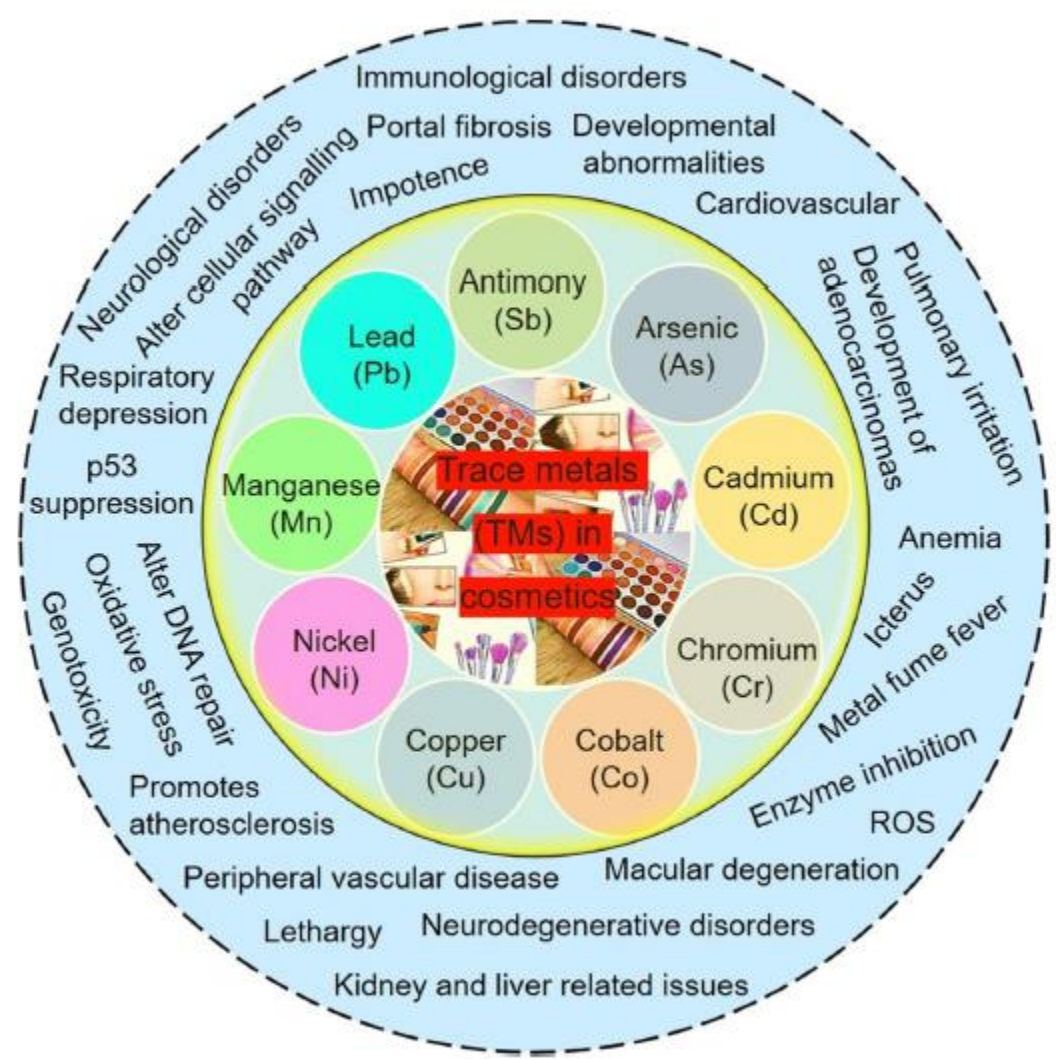

Fig-1: Several Untoward Effects Exerted by Heavy Metal Exposure from Cosmetics [1-3]. The global cosmetic products market was valued at USD 382.3 billion in 2010, 532.43 billion in 2017, and is expected to reach a market value of USD 805.61 billion by 2023, registering a Compound Annual Growth Rate (CAGR) of 7.14\% during 2018-2023. Social media is key to the shift in consumer demand. Trends are shared more quickly and emotively, with celebrities and influencers - as well as everyday people - posting content which urges everyone to become a conscious consumer. The presence of heavy metals and xenobiotics are not normally considered as a primary concern in cosmetics. With many new products released into the market every season, it is hard to keep track of the safety of every product and some products may carry carcinogenic contaminants, while some others raise many more detrimental issues.

\section{ACKNOWLEDGEMENT}

I'm thankful to Dr. Alessandra Panico, Department of Biological and Environmental Science and Technology, University of Salento, Lecce, Italy for her valuable time to audit my paper and for her thoughtful suggestions. I'm also grateful to seminar library of Faculty of Pharmacy, University of Dhaka and BANSDOC Library, Bangladesh for providing me books, journal and newsletters.

\section{Abbreviations}

Compound Annual Growth Rate (CAGR); allergic contact dermatitis (ACD); Cosmetic Ingredient Review (CIR); Type-2 Diabetes Mellitus (T2DM): Environmental Working Group (EWG)

\section{Financial Disclosure or Funding: N/A}

Conflict of Interest: The author declares that he has no competing interests.

\section{Informed Consent: N/A}

\section{Author contributions: N/A}




\section{REFERENCES}

1. Bilal, M., \& Iqbal, H. M. (2019). An insight into toxicity and human-health-related adverse consequences of cosmeceuticals-a review. Science of the total environment, 670:555-568.

2. Bakr, R. O., Amer, R. I., Fayed, M. A., \& Ragab, T. I. (2019). A completely polyherbal conditioning and antioxidant shampoo: A phytochemical study and pharmaceutical evaluation. Journal of pharmacy \& bioallied sciences, 11(2), 105-115.

3. Reuters. Global Cosmetics Products Market expected to reach USD 805.61 billion by 2023 - Industry Size \& Share Analysis. Featured News, 13 March, 2018.

4. Zanolli, L. (2019). Pretty hurts: are chemicals in beauty products making us ill? The Guardian.

5. Gowhar, S. A. (2018). Harmful effects of beauty care products on human health. International Journal of Medical Science and Public Health, 7(1), 1-9.

6. Naveed, N. (2014). The perils of cosmetics. Journal of Pharmaceutical Sciences and Research, 6(10), 338-341. Available From: https://www.jpsr.pharmainfo.in/Documents/Volumes/Vol6lssue10/jpsr06101402.pdf

7. St. Pierre B. Safe cosmetics: What's in your bathroom cabinet? Available From: https://www.precisionnutrition.com/all-about-safecosmetics

8. Milman, O. (2019). US cosmetics are full of chemicals banned by Europe - why? The Guardian, 22 May 2019.

9. Anne Houtman, S. K. A. J. I. (2013). Toxic bottles? On the trail of chemicals in our every day lives. In: Correa, J. (Ed.), American Environmental Science for a Changing World. Kate Ahr Paker (p. 54).

10. Ahsan, H. (2019). The biomolecules of beauty: biochemical pharmacology and immunotoxicology of cosmeceuticals. Journal of Immunoassay and Immunochemistry, 40(1), 91-108.

11. Omenka, S. S., \& Adeyi, A. A. (2016). Heavy metal content of selected personal care products (PCPs) available in Ibadan, Nigeria and their toxic effects. Toxicology reports, 3, 628-635.

12. Alam, M. F., Akhter, M., Mazumder, B., Ferdous, A., Hossain, M. D., Dafader, N. C., ... \& Ullah, A. A. (2019). Assessment of some heavy metals in selected cosmetics commonly used in Bangladesh and human health risk. Journal of Analytical Science and Technology, 10(1), 2.

13. Vella, A., \& Attard, E. (2019). Analysis of Heavy Metal Content in Conventional and Herbal Toothpastes Available at Maltese Pharmacies. Cosmetics, 6(2), 28.

14. Łodyga-Chruścińska, E., Sykuła, A., \& Więdłocha, M. (2018). Hidden Metals in Several Brands of Lipstick and Face Powder Present on Polish Market. Cosmetics, 5(4), 57.

15. Panico, A., Serio, F., Bagordo, F., Grassi, T., Idolo, A., De Giorgi, M., ... \& De Donno, A. (2019). Skin safety and health prevention: an overview of chemicals in cosmetic products. Journal of Preventive Medicine and Hygiene, 60(1), E50 -E57.

16. Khan, F. (2019). Is surma safe for newborn eyes? Daily Times (Pakistan), 24 March, 2019.

17. McMichael, J. R., \& Stoff, B. K. (2018). Surma eye cosmetic in Afghanistan: a potential source of lead toxicity in children. European journal of pediatrics, 177(2), 265-268.

18. De, J. C. (2009). Lead poisoning caused by prolonged use of kohl, an underestimated cause in French-speaking countries. Journal francais d'ophtalmologie, 32(7), 459-463.

19. Centers for Disease Control and Prevention (CDC. (2012). Infant lead poisoning associated with use of tiro, an eye cosmetic from Nigeria--Boston, Massachusetts, 2011. MMWR. Morbidity and mortality weekly report, 61(30), 574.

20. Schwarcz, L., Begay, C. L., Chilton, L. A., Shirley, J. B., \& Seifert, S. A. (2013). Childhood lead exposure associated with the use of kajal, an eye cosmetic from Afghanistan-Albuquerque, New Mexico, 2013. MMWR. Morbidity and mortality weekly report, 62(46), 917-919.

21. Sprinkle, R. V. (1995). Leaded eye cosmetics: a cultural cause of elevated lead levels in children. Journal of family practice, 40(4), 358-363.

22. Massadeh, A. M., El-Khateeb, M. Y., \& Ibrahim, S. M. (2017). Evaluation of Cd, Cr, Cu, Ni, and Pb in selected cosmetic products from Jordanian, Sudanese, and Syrian markets. Public health, 149, 130-137.

23. Lim, J. S. J., Ho, Y. B., \& Hamsan, H. (2017). Heavy metals contamination in eye shadows sold in Malaysia and user's potential health risks. Annals of Tropical Medicine and Public Health, 10(1), 56-64.

24. Nourmoradi, H., Foroghi, M., Farhadkhani, M., \& Vahid Dastjerdi, M. (2013). Assessment of lead and cadmium levels in frequently used cosmetic products in Iran. Journal of environmental and public health, 2013:962727.

25. Salama, A. K. (2016). Assessment of metals in cosmetics commonly used in Saudi Arabia. Environmental monitoring and assessment, 188(10), 553.

26. ALqadami, A., Abdalla, M., ALOthman, Z., \& Omer, K. (2013). Application of solid phase extraction on multiwalled carbon nanotubes of some heavy metal ions to analysis of skin whitening cosmetics using ICP-AES. International journal of environmental research and public health, 10(1), 361-374.

27. Sani, A., Gaya, M. B., \& Abubakar, F. A. (2016). Determination of some heavy metals in selected cosmetic products sold in kano metropolis, Nigeria. Toxicology reports, 3, 866-869.

28. Iwegbue, C. M., Emakunu, O. S., Obi, G., Nwajei, G. E., \& Martincigh, B. S. (2016). Evaluation of human exposure to metals from some commonly used hair care products in Nigeria. Toxicology reports, 3, 796-803.

29. Unsal, V. (2018). Natural Phytotherapeutic Antioxidants in the Treatment of Mercury Intoxication-A Review. Advanced pharmaceutical bulletin, 8(3), 365-376. 
30. Shah, M. P., Shendell, D. G., Strickland, P. O., Bogden, J. D., Kemp, F. W., \& Halperin, W. (2017). Lead content of sindoor, a Hindu religious powder and cosmetic: New Jersey and India, 2014-2015. American journal of public health, 107(10), $1630-1632$.

31. Fischer, A., Brodziak-Dopierała, B., Loska, K., \& Stojko, J. (2017). The Assessment of Toxic Metals in Plants Used in Cosmetics and Cosmetology. International journal of environmental research and public health, 14(10), 1280.

32. Alissa, E. M., \& Ferns, G. A. (2011). Heavy metal poisoning and cardiovascular disease. Journal of toxicology, 2011:870125.

33. Saadatzadeh, A., Afzalan, S., Zadehdabagh, R., Tishezan, L., Najafi, N., Seyedtabib, M., \& Noori, S. M. A. (2019). Determination of heavy metals (lead, cadmium, arsenic, and mercury) in authorized and unauthorized cosmetics. Cutaneous and ocular toxicology, 1-5.

34. Not Just Virat Kohli, Here Are Other Celebs Who Said No To Endorsements On Ethical Grounds. SCOOPWHOOP, Sep 14, 2017.

35. Gondal, M. A., Dastageer, M. A., Naqvi, A. A., Isab, A. A., \& Maganda, Y. W. (2012). Detection of toxic metals (lead and chromium) in talcum powder using laser induced breakdown spectroscopy. Applied optics, 51(30), 7395-7401.

36. Orisakwe, O. E., \& Otaraku, J. O. (2013). Metal concentrations in cosmetics commonly used in Nigeria. The Scientific World Journal, 2013:959637.

37. Aldayel, O., Hefne, J., Alharbi, K. N., \& Al-Ajyan, T. (2018) Heavy Metals Concentration in Facial Cosmetics. Nat Prod Chem Research, 6: 303.

38. Capelli, C., Foppiano, D., Venturelli, G., Carlini, E., Magi, E., \& lanni, C. (2014). Determination of arsenic, cadmium, cobalt, chromium, nickel, and lead in cosmetic face-powders: optimization of extraction and validation. Analytical Letters, 47(7), 1201 1209.

39. Schwalfenberg, G., Rodushkin, I., \& Genuis, S. J. (2018). Heavy metal contamination of prenatal vitamins. Toxicology reports, 5 390-395

40. Wang, Y., Chen, L., Gao, Y., Zhang, Y., Wang, C., Zhou, Y., ... \& Tian, Y. (2016). Effects of prenatal exposure to cadmium on neurodevelopment of infants in Shandong, China. Environmental pollution, 211, 67-73.

41. Henn, B. C., Ettinger, A. S., Hopkins, M. R., Jim, R., Amarasiriwardena, C., Christiani, D. C., ... \& Wright, R. O. (2016). Prenatal arsenic exposure and birth outcomes among a population residing near a mining-related superfund site. Environmental health perspectives, 124(8), 1308-1315.

42. Li, H., Zheng, J., Wang, H., Huang, G., Huang, Q., Feng, N., \& Xiao, J. (2019). Maternal cosmetics use during pregnancy and risks of adverse outcomes: a prospective cohort study. Scientific reports, 9(1), 8030.

43. Bruzzoniti, M. C., Abollino, O., Pazzi, M., Rivoira, L., Giacomino, A., \& Vincenti, M. (2017). Chromium, nickel, and cobalt in cosmetic matrices: an integrated bioanalytical characterization through total content, bioaccessibility, and $\mathrm{Cr}(\mathrm{III}) / \mathrm{Cr}(\mathrm{VI})$ speciation. Analytical and bioanalytical chemistry, 409(29), 6831-6841.

44. Brown, V. J. (2013). Metals in Lip Products-A Cause for Concern? Environ Health Perspect, 121(6):A196.

45. Klotz, K., Weistenhöfer, W., Neff, F., Hartwig, A., van Thriel, C., \& Drexler, H. (2017). The health effects of aluminum exposure. Deutsches Ärzteblatt International, 114(39), 653-659.

46. Becker, L. C., Boyer, I., Bergfeld, W. F., Belsito, D. V., Hill, R. A., Klaassen, C. D., ... \& Snyder, P. W. (2016). Safety assessment of alumina and aluminum hydroxide as used in cosmetics. International journal of toxicology, 35(3_suppl), 16S-33S.

47. Mohiuddin, A. K. (2019). Cosmetics in use: a pharmacological review. Journal Dermat Cosmetol, 3(2):50-67.

48. Ajaezi, G. C., Amadi, C. N., Ekhator, O. C., Igbiri, S., \& Orisakwe, O. E. (2018). Cosmetic Use in Nigeria May Be Safe: A Human Health Risk Assessment of Metals and Metalloids in Some Common Brands. Journal of cosmetic science, 69(6), $429-445$.

49. Alizadeh, A., Balali-Mood, M., Mahdizadeh, A., \& Riahi-Zanjani, B. (2017). Mercury and Lead Levels in Common Soaps from Local Markets in Mashhad, Iran. Iran J Toxicol, 11(4), 1-3.

50. Mohammed, T., Mohammed, E., \& Bascombe, S. (2017). The evaluation of total mercury and arsenic in skin bleaching creams commonly used in Trinidad and Tobago and their potential risk to the people of the Caribbean. Journal of public health research, 6(3):1097.

51. Sneyers, L., Verheyen, L., Vermaercke, P., \& Bruggeman, M. (2009). Trace element determination in beauty products by k 0 instrumental neutron activation analysis. Journal of radioanalytical and nuclear chemistry, 281(2), 259-263.

52. Lavilla, I., Cabaleiro, N., Costas, M., De la Calle, I., \& Bendicho, C. (2009). Ultrasound-assisted emulsification of cosmetic samples prior to elemental analysis by different atomic spectrometric techniques. Talanta, 80(1), 109-116.

53. Chan, T. Y., Chan, A. P., \& Tang, H. L. (2019). Nephrotic syndrome caused by exposures to skin-lightening cosmetic products containing inorganic mercury. Clinical Toxicology, 1-7.

54. Qin, A. B., Su, T., Wang, S. X., Zhang, F., \& Zhao, M. H. (2019). Mercury-associated glomerulonephritis: a retrospective study of 35 cases in a single Chinese center. BMC nephrology, 20(1), 228.

55. Doshi, M., Annigeri, R. A., Kowdle, P. C., Subba Rao, B., \& Varman, M. (2018). Membranous nephropathy due to chronic mercury poisoning from traditional Indian medicines: report of five cases. Clinical kidney journal, 12(2), 239-244.

56. Zhang, L., Liu, F., Peng, Y., Sun, L., \& Chen, C. (2014). Nephrotic syndrome of minimal change disease following exposure to mercury-containing skin-lightening cream. Annals of Saudi medicine, 34(3), 257-261.

57. García, J. D. D., \& Arceo, E. (2018). Renal damage associated with heavy metals: review work. Revista Colombiana de Nefrología, 5(1), 45-53.

58. Orr, S., \& Bridges, C. (2017). Chronic kidney disease and exposure to nephrotoxic metals. International journal of molecular sciences, 18(5), 1039. 
59. Tibau, A. V., \& Grube, B. D. (2019). Mercury Contamination from Dental Amalgam. Journal of Health and Pollution, 9(22), 190612.

60. Mohiuddin, A. K. (2019). Skin Lighteners \& Hyperpigmentation Management. ASIO Journal of Pharmaceutical \& Herbal Medicines Research (ASIO - JPHMR), 5(1), 1-42.

61. Sun, G. F., Hu, W. T., Yuan, Z. H., Zhang, B. A., \& Lu, H. (2017). Characteristics of mercury intoxication induced by skinlightening products. Chinese medical journal, 130(24), 3003-3004.

62. Wang, X., Mukherjee, B., \& Park, S. K. (2018). Associations of cumulative exposure to heavy metal mixtures with obesity and its comorbidities among US adults in NHANES 2003-2014. Environment international, 121, 683-694.

63. Wani, A. L., Ara, A., \& Usmani, J. A. (2015). Lead toxicity: a review. Interdiscip Toxicol 8: 55-64.

64. Assi, M. A., Hezmee, M. N. M., Haron, A. W., Sabri, M. Y. M., \& Rajion, M. A. (2016). The detrimental effects of lead on human and animal health. Veterinary world, 9(6), 660-671.

65. Sanders, T., Liu, Y., Buchner, V., \& Tchounwou, P. B. (2009). Neurotoxic effects and biomarkers of lead exposure: a review. Reviews on environmental health, 24(1), 15-46.

66. Cecil, K. M., Brubaker, C. J., Adler, C. M., Dietrich, K. N., Altaye, M., Egelhoff, J. C., ... \& Lanphear, B. P. (2008). Decreased brain volume in adults with childhood lead exposure. PLoS medicine, 5(5), e112.

67. Mason, L. H., Harp, J. P., \& Han, D. Y. (2014). Pb neurotoxicity: neuropsychological effects of lead toxicity. BioMed research international, 2014: 840547.

68. Kim, H. C., Jang, T. W., Chae, H. J., Choi, W. J., Ha, M. N., Ye, B. J., ... \& Hong, Y. S. (2015). Evaluation and management of lead exposure. Annals of occupational and environmental medicine, 27(1), 30.

69. Stewart, W. F., \& Schwartz, B. S. (2007). Effects of lead on the adult brain: A 15-year exploration. American Journal of Industrial Medicine, 50(10), 729-739.

70. Liu, K. S., Hao, J. H., Zeng, Y., Dai, F. C., \& Gu, P. Q. (2013). Neurotoxicity and biomarkers of lead exposure: a review. Chinese Medical Sciences Journal, 28(3), 178-188.

71. Kwon, S. Y., Bae, O. N., Noh, J. Y., Kim, K., Kang, S., Shin, Y. J., ... \& Chung, J. H. (2014). Erythrophagocytosis of lead-exposed erythrocytes by renal tubular cells: possible role in lead-induced nephrotoxicity. Environmental health perspectives, 123(2), 120127.

72. Hauptman, M., Bruccoleri, R., \& Woolf, A. D. (2017). An update on childhood lead poisoning. Clinical pediatric emergency medicine, 18(3), 181-192.

73. Rana, M. N., Tangpong, J., \& Rahman, M. M. (2018). Toxicodynamics of lead, cadmium, mercury and arsenic-induced kidney toxicity and treatment strategy: a mini review. Toxicology reports, 5, 704-713.

74. Kute, V. B., Shrimali, J. D., Balwani, M. R., Godhani, U. R., Vanikar, A. V., Shah, P. R., ... \& Trivedi, H. L. (2013). Lead nephropathy due to Sindoor in India. Renal failure, 35(6), 885-887.

75. Reilly, R., Spalding, S., Walsh, B., Wainer, J., Pickens, S., Royster, M., ... \& Little, B. B. (2018). Chronic environmental and occupational lead exposure and kidney function among African Americans: Dallas Lead Project II. International journal of environmental research and public health, 15(12), 2875.

76. Cleveland, L. M., Minter, M. L., Cobb, K. A., Scott, A. A., \& German, V. F. (2008). Lead hazards for pregnant women and children: part 1: immigrants and the poor shoulder most of the burden of lead exposure in this country. Part 1 of a two-part article details how exposure happens, whom it affects, and the harm it can do. AJN The American Journal of Nursing, 108(10), 40-49.

77. Bakhireva, L. N., Rowland, A. S., Young, B. N., Cano, S., Phelan, S. T., Artyushkova, K., ... \& Lewis, J. (2013). Sources of potential lead exposure among pregnant women in New Mexico. Maternal and child health journal, 17(1), 172-179.

78. Vigeh, M., Yokoyama, K., Kitamura, F., Afshinrokh, M., Beygi, A., \& Niroomanesh, S. (2010). Early pregnancy blood lead and spontaneous abortion. Women \& health, 50(8), 756-766.

79. Taylor, C. M., Golding, J., \& Emond, A. M. (2015). Adverse effects of maternal lead levels on birth outcomes in the ALSPAC study: a prospective birth cohort study. BJOG: An International Journal of Obstetrics \& Gynaecology, 122(3), 322-328.

80. Al Jameil, N. (2014). Maternal serum lead levels and risk of preeclampsia in pregnant women: a cohort study in a maternity hospital, Riyadh, Saudi Arabia. International journal of clinical and experimental pathology, 7(6), 3182-3189.

81. Riess, M. L., \& Halm, J. K. (2007). Lead poisoning in an adult: lead mobilization by pregnancy?. Journal of general internal medicine, 22(8), 1212-1215.

82. Marzulli, F. N., Watlington, P. M., \& Maibach, H. I. (1978). Exploratory skin penetration findings relating to the use of lead acetate hair dyes. Hair as a test tissue for monitoring uptake of systemic lead. Current problems in dermatology, 7, 196-204.

83. Liu, B., Jin, S. F., Li, H. C., Sun, X. Y., Yan, S. Q., Deng, S. J., \& Zhao, P. (2019). The Bio-Safety Concerns of Three Domestic Temporary Hair Dye Molecules: Fuchsin Basic, Victoria Blue B and Basic Red 2. Molecules, 24(9), 1744.

84. Sampathkumar, K., \& Yesudas, S. (2009). Hair dye poisoning and the developing world. Journal of emergencies, trauma and shock, 2(2), 129.

85. Saitta, P., Cook, C. E., Messina, J. L., Brancaccio, R., Wu, B. C., Grekin, S. K., \& Holland, J. (2013). Is There a true concern regarding the use of hair dye and malignancy development?: A review of the epidemiological evidence relating personal hair dye use to the risk of malignancy. The Journal of clinical and aesthetic dermatology, 6(1), 39-46.

86. Vigeh, M., Smith, D. R., \& Hsu, P. C. (2011). How does lead induce male infertility?. Iranian journal of reproductive medicine, $9(1), 1$. 
87. Wu, H. M., Lin-Tan, D. T., Wang, M. L., Huang, H. Y., Lee, C. L., Wang, H. S., ... \& Lin, J. L. (2012). Lead level in seminal plasma may affect semen quality for men without occupational exposure to lead. Reproductive Biology and Endocrinology, 10(1), 91.

88. Rehman, S., Usman, Z., Rehman, S., AIDraihem, M., Rehman, N., Rehman, I., \& Ahmad, G. (2018). Endocrine disrupting chemicals and impact on male reproductive health. Translational andrology and urology, 7(3), 490-503.

89. Flora, G., Gupta, D., \& Tiwari, A. (2012). Toxicity of lead: a review with recent updates. Interdisciplinary toxicology, 5(2), 47-58.

90. Ettinger, A. S., Ruckart, P. Z., \& Dignam, T. (2019). Lead Poisoning Prevention: The Unfinished Agenda. Journal of public health management and practice: JPHMP, 25(Suppl 1 LEAD POISONING PREVENTION), S1-S2.

91. Ettinger, A. S., Leonard, M. L., \& Mason, J. (2019). CDC's Lead Poisoning Prevention Program: A Long-standing Responsibility and Commitment to Protect Children From Lead Exposure. Journal of public health management and practice: JPHMP, 25(Suppl 1 Lead Poisoning Prevention), S5-S12.

92. Bruce, S. A., Christensen, K. Y., Coons, M. J., Havlena, J. A., Meiman, J. G., \& Walsh, R. O. (2019). Using Medicaid Data to Improve Childhood Lead Poisoning Prevention Program Outcomes and Blood Lead Surveillance. Journal of Public Health Management and Practice, 25, S51-S57.

93. Gondal, M. A., Seddigi, Z. S., Nasr, M. M., \& Gondal, B. (2010). Spectroscopic detection of health hazardous contaminants in lipstick using laser induced breakdown spectroscopy. Journal of Hazardous Materials, 175(1-3), 726-732.

94. Lim, D. S., Roh, T. H., Kim, M. K., Kwon, Y. C., Choi, S. M., Kwack, S. J., ... \& Lee, B. M. (2018). Non-cancer, cancer, and dermal sensitization risk assessment of heavy metals in cosmetics. Journal of Toxicology and Environmental Health, Part A, 81(11), 432-452.

95. Hwang, M., Yoon, E. K., Kim, J. Y., Son, B. K., Yang, S. J., Yun, M. O., ... \& Yoo, T. M. (2009). Safety assessment of chromium by exposure from cosmetic products. Archives of pharmacal research, 32(2), 235-241.

96. Thyssen, J. P., Johansen, J. D., \& Menné, T. (2007). Contact allergy epidemics and their controls. Contact Dermatitis, 56(4), 185195.

97. Kang, E. K., Lee, S., Park, J. H., Joo, K. M., Jeong, H. J., \& Chang, I. S. (2006). Determination of hexavalent chromium in cosmetic products by ion chromatography and postcolumn derivatization. Contact dermatitis, 54(5), 244-248.

98. Wilbur, S., Abadin, H., \& Fay, M. Toxicological Profile for Chromium. Atlanta (GA): Agency for Toxic Substances and Disease Registry (US); 2012 Sep. 3, Health Effects. Available from: https://www.ncbi.nlm.nih.gov/books/NBK158851/

99. Shelnutt, S. R., Goad, P., \& Belsito, D. V. (2007). Dermatological toxicity of hexavalent chromium. Critical reviews in toxicology, 37(5), 375-387.

100. Theresa, O. C., Onebunne, O. C., Dorcas, W. A., \& Ajani, O. I. (2011). Potentially toxic metals exposure from body creams sold in Lagos, Nigeria. Researcher, 3(1), 30-37.

101. Chen, Q. Y., DesMarais, T., \& Costa, M. (2019). Metals and mechanisms of carcinogenesis. Annual review of pharmacology and toxicology, 59, 537-554.

102. Martin, C. J., Werntz III, C. L., \& Ducatman, A. M. (2004). The interpretation of zinc protoporphyrin changes in lead intoxication: a case report and review of the literature. Occupational Medicine, 54(8), 587-591.

103. Piao, F., Yokoyama, K., Ma, N., \& Yamauchi, T. (2003). Subacute toxic effects of zinc on various tissues and organs of rats. Toxicology letters, 145(1), 28-35.

104. Yeomans, M. (2014). Copper - the anti-aging ingredient of this decade? CosmeticsDesign (USA), 24 March, 2014.

105. Li, H., Toh, P. Z., Tan, J. Y., Zin, M. T., Lee, C. Y., Li, B., ... \& Kang, L. (2016). Selected biomarkers revealed potential skin toxicity caused by certain copper compounds. Scientific reports, 6, 37664.

106. Magaye, R. R., Yue, X., Zou, B., Shi, H., Yu, H., Liu, K., ... \& Zhao, J. (2014). Acute toxicity of nickel nanoparticles in rats after intravenous injection. International journal of nanomedicine, 9, 1393-1402.

Thompson, L. Cobalt in Cosmetics: Is it safe? Available from: https://feelgoodstyle.com/articles/cobalt-in-cosmetics/ 